\title{
The application of ADDIE teaching design model in new-type professional farmer cultivation
}

\author{
Sun Tieyu \\ Hainan Radio and TV University, Haikou, Hainan, China \\ 22720068@qq.com
}

Keywords: Teaching design model, ADDIE model, New professional farmer training.

\begin{abstract}
In the field of education and training, the visualization and operability of the ADDIE model become the guiding teaching design model. In order to solve the problem that the content of training in new professional farmers in Hainan Province is not pertinent, practicality is not high and the overall level of precision cultivation is not high, this paper elaborates the analysis, design, development, implementation and evaluation of ADDIE teaching design model Link in the cultivation of new types of professional farmers in order to systematically and effectively optimize the education and training programs, adjust the education and training process, improve the effectiveness of education and training.
\end{abstract}

\section{ADDIE教学设计模型在新型职业农民培育中的应用}

\author{
孙铁玉 \\ 海南广播电视大学, 海口, 海南, 中国 \\ 22720068@qq.com
}

关键词：教学设计模型; ADDIE模式；新型职业农民培育

中文摘要. 在教育培训领域, ADDIE模型的可视化和可操作性成为指导性教学设计模型。为 解决海南新型职业农民培育中存在的培训内容针对性不强、实用性不高、精准培育总体程度 不高的问题，本文通过阐述ADDIE教学设计模型的分析、设计、开发、实施与评价五个环节 在新型职业农民培育中的应用, 以期系统有效地优化教育培训方案, 调整教育培训过程, 提 高教育培训效果。

\section{1. 引言}

2012年以来，按照党中央国务院的部署要求，农业部、财政部等部门启动实施了新型职 业农民的教育培训工程。建立一套系统化、步骤化的教学设计方法, 对提升新型职业农民教 育培训的实效性具有重要的实践意义。因农民个体农业生产、工作及生活经验对学习活动有 较大影响, 新型职业农民教育培训就应更多地考虑学习者的参与。ADDIE通用模型中的分析

(Analysis)、设计 (Design)、开发 (Development)、实施 (Implementation) 和评估 (Evaluation) 五个阶段, 既包括了典型教学系统设计的主要环节, 也与农民想要获取实用、可靠、明确、 可信的学习意愿相吻合。 


\section{2. 分析阶段}

ADDIE教学设计模型在新型职业农民培育中的应用, 必须明确每一个环节的关键点。分 析阶段是ADDIE模型的首要环节, 也是新型职业农民培育顺利有效开展的前提和基础。这一 环节的关键点是学习需求分析, 主要包括对学习对象、学习需求、学习内容的分析。

\section{1 学习对象分析}

在对海口、万宁、澄迈、三亚、儋州、临高、琼中、昌江、定安、屯昌等新型职业农民 培育示范市县的相关调研中发现: 海南农民文化素质不高, 高中及以下所占比重较大; 年龄 偏大，41-60岁为新型职业农民培育的主要年龄段; 家庭收入普遍较低，有较为丰富的农业生 产经验, 自主学习能力较差, 对农业新知识新技能接受能力较弱, 参加教育培训的意愿不强。 基于农民学习者的上述特征, 新型职业农民培育教学设计要与其年龄、文化基础、认知能力 完整对接, 通过分层次、分类型的教学培训类型和教学内容的设计, 达到既满足大多数农民 传统种、养殖生产中岗位任职要求的基础知识和基本技能的初级层次的需要, 也满足中、高 级层次农民较强的创新能力、决策能力和管理能力的需要, 并在资金、项目、融资、建设、 保障政策等多个方面鼓励和扶持新型职业农民的发展。

\section{2 学习需求分析}

对学生学习需求和学习特点的研究, 并培育需求和引领需求, 是实现新型职业农民精准 培育的要求。在对海南新型职业农培育的调查研究中, 通过教育培训增加收入和提高农业生 产技能是农民最大的意愿，反映出农民认识到自身的知识和技能的欠缺是导致其增收致富的 重要原因。其中: 农民对专业知识需求高于基础知识需求, 专业基础能力和专业核心能力的 需求较为突出。农民学习者由于自身文化程度不高, 自主学习能力和知识接受能力都较低, 因此要改变农民教育培训中的被动学习状态, 通过广泛宣传、引导及科学实用的教学设计, 激发农民的学习动机, 调动农民学习的主动性和积极性。

\section{3 学习内容分析}

新型职业农民主要包括生产经营型、专业技能型和专业服务型三类。根据《“十三五”全 国新型职业农民培育发展规划》，生产经营型职业农民培育对象主要以专业大户、家庭农场 经营者、农民合作社带头人、农业企业骨干和返乡下乡创业者为主; 专业技能型职业农民培 育对象主要以在新型农业经营主体稳定就业的农业工（农业雇员）为主; 专业服务型职业农 民培育对象主要以从事农业产前、前中、产后经营性服务的骨干人员为主。三类协同发展的 新型职业农民教育培训的内容应有所区分, 各有侧重。在海南, 生产经营型职业农民的学习 内容应以海南热带高效农业为主, 侧重全产业链技能所需要的知识和技能, 提高农民的经营 管理水平，促进扩大产业经营规模; 专业技能型以农业新知识、新技术、新品种、新成果为 主, 提高其专业化生产能力, 侧重培养各专项知识和技能; 专业服务型以现代设施农业和规 模农业为主，侧重培养农业社会化服务知识和技能。

\section{3. 设计阶段}

设计阶段的关键点是如何教的问题, 主要包括明确教学目标, 选择教学方法和教学手段。

\section{1 教学目标}

新型职业农民是以农业为职业，具有相应的专业技能、收入主要来自农业生产经营并达 到相当水平的现代农业从者。教学目标是培养“有文化、懂技术、会经营、负责任、有地位” 的职业农民。因此, 在教学目标设计中, 体现综合素质能力目标（热爱农业生产、珍惜农业 资源；诚实守信；良好的沟通协调；接受新技术新观念；重视社会责任。）、生产技能目标 
（掌握农业行业知识与技术; 关注农业发展新趋势）和经营管理能力目标（具有市场观念、 管理意识和创新思维）。需要注意的是, 海南新型职业农民培训还担负着贫困农民脱贫致富 的重任，对于相当一部分贫困户而言，“等靠要”思想严重，甚至把党的扶贫好政策错误地当 成了养懒人的政策，争着当贫困户。习总书记强调，扶贫先扶志，扶贫必扶智，“志智双扶” 是打赢脱贫攻坚战的根本之策。因此，在新型职业农民教育培训目标中要通过树立脱贫致富、 致富带头人等典型, 融入感恩、励志教育, 激发贫困群众的内生动力, 为海南热带农业和全 域旅游发展

\section{2 教学方法}

根据新型职业农民的学习需求和培养目标，专业基础能力应为培养目标中的重之中重。 因此, 在理论与实践相结合、集中培训与现场实训相结合的教学中, 在田间地头、创业孵化 园、顶岗实训基地等真实或模拟的“职业场所”通过“菜单式学习”、“体验式学习圈”等多种教 学方法体系, 实现教学的实用性, 提高农民的学习积极性。

\section{3 教学手段}

随着现代教育技术与教育的深度融合，在新型职业农民培育中，加强在线开放教学服务， 包括学前、学中和学后以及产前、产中和产后, 多渠道多平台, 发挥互联网+的优势, 通过线 上十线下方式, 借助网络教学平台、微信公众号、QQ群等, 或答疑解惑, 或弥补教学中的薄 弱环节，或满足个性化学习需求的辅助和支持。

\section{4. 开发阶段}

开发阶段的关键点是选择合适的教学资源。

教学资源的开发基于教学设计, 也成为教学设计的核心环节, 包括教师、教材、教具、 教学媒介、教学场景及其他辅助教学资源的选取和配置。针对新型职业农民培育的特点, 教 师的遴选除了要求匹配农民需求的理论知识、实践技能等教学能力, 还要更多地承担农民学 员学习引领者、知识构建者、学习服务支持者、情感交流者的角色。而在教材、教学媒介等 资源的开发中, 需要注意的是：第一, 由于新型职业农民培育要立足产业, 把服务现代农业 产业作为出发点和落脚点, 而农业发展中自然资源条件的差异, 因此在资源的开发中既要因 地制宜, 细化原有教学资源, 使新型职业农民教育培训为地方农业产业发展服务, 也要将农 业领域不断涌现的新知识、新技能、新特点和新趋势引入到教学中。第二, 根据新型职业农 民培育生产经营型、专业技能型和专业服务型”三类协同“发展，初级、中级、高级“三级贯通” 的培养目标, 各类教学资源的开发, 除了包括课堂面授课的教学课件、教学大纲等传统教学 资源外，还应注重微课视频、慕课视频的开发。

\section{5. 实施阶段}

实施阶段的关键点是实现师生的教学交互, 达到学生汲取知识、提升能力并激发其学习 热情的目的。由于农民有着更丰富的生产、生活及人生体验, 大卫.库伯(David kolb)的经验学 习模式亦即经验学习圈理论(experiential learning)应用到新型职业农民培育的实施阶段, 可以 更大限度地兼顾各种学习风格的农民学习者的学习兴趣和学习需求, 达到农民培育效益的最 大化。经验学习模式通过四个适应性学习阶段, 即让学员获得体验、引导学员进行反思、过 渡上升到理论知识、引发学员将培训所得应用于实践得以实施完成。经验学习模式确保培训 活动是一个完整的学习过程。研究证明, 如果遵循了这个学习过程, 人们的学习更为有效, 学习成果保留的时间会更长, 还会有利于培养更有效的行为技能。同时, 依照一个完整的学 习过程来实施培训活动, 将有助于不同学习风格的学员在自己不擅长的学习阶段里逐步弥补 
自己的不足, 毕竟各种风格都有长处和短处, 在完整的学习过程里, 会潜移默化, 相互感染, 彼此欣赏, 取长补短。

在实施经验式学习模式时, 需要注意的是:

第一，要以农民获得体验为中心。教学实施过程中，农民学员是主角，让其以经验为基 础的参与在实施阶段起主导作用。例如在海南省开展的新型职业农民培育工程生产经营型露 地蔬菜生产培训中，针对瓜菜种植大户、种养大户、合作社负责人、部分贫困户等不同层次 的农民学员, 采取了“分段式、重实训、参与式”的精准教育培训, 培训效果得到了当地政府 和农民的好评。

第二, 要创造良好的培训学习环境。学习环境的设计，要能够吸引农民学员的注意力, 因此多以农民学员在其农业生产、工作、生活中面临的现实问题为主, 由于这些问题直接或 间接地影响着农民增收, 通过在与真实环境相同或相似的学习环境的学习, 农民学员会获得 解决这些问题的真实体验并把培训所学直接应用到现实情境中, 或者迁移到其他类似问题的 解决上。和已往的生产、工作、生活体验相关联的问题随着培训的进行一一得以解决, 从而 持续引起农民学习的兴趣。

第三, 教师的角色是教育培训的组织者。农民学员直于自身能力限制, 如果仅仅靠自身 的力量, 而没有教师的引导和反馈, 将会影响其学习效率, 因此, 教师要有效地提供帮助和 指导, 并善于引导农民学员之间的协作与交流。为了达到较好的培训效果, 教师还要做好分 班工作，一般以20～30人为宜，以保证每个农民学员都有机会参与体验。

第四, 重视信息反馈。为了增强农民学员之间以及农民学员与外界的互动, 让农民学员 进一步深入认识自我, 教师要关注学习过程中的种种反馈信息, 以发现学习中的问题, 在学 习中解决问题, 从而修正教育培训计划, 提升学习效果。

\section{6. 评价阶段}

这一阶段的关键点是对所有教学环节的指导和监督, 包括建立多元化的评价指标体系和 采取耿活多样的考核方式。

\section{1 建立多元化的评价指标体系}

新型职业农民教育培训多以培训人数和规模两项指标进行评价, 这是一种重效率、轻效 果的评价观念, 不利于形成合理的教育培训项目层次目标, 这种单一的评价指标体系也难以 解决培训类型结构不合理问题。因此, 为达到新型职业农民培育对当地经济发展的促进, 实 现农业增效、农民增收的目标, 应将教育培训的主体（政府的财政投入、政策支持等）、培 育的内容（文化知识、种植、养殖知识、农业经营管理知识等）、培育的方式、培育机构以 及培育环境等纳入评价指标体系中，真正体现对周期较长的教育培训效益的评价。

\section{2 采取灵活多样的考核方式}

注重过程监督和考核，并辅以完备的监督管理机制和保障措施，以确立教育培训对农民 学员知识及技能的提升能力和学习积极性的调动, 保证评价环节的真实有效。

\section{7. 结束语}

ADDIE教学设计模型对当代教育发展有着重要的启示作用。作为系统化、步骤化的教育 教学方法, 将ADDIE模型运用在新型职业农民教育培训中, 通过分析、设计、开发、实施和 评估五个环节的构建, 对农民学员而言, 有效解决了教育培训中为什么学、学什么、怎么学 的问题, 进而激发农民学员这一群体的内生学习动力, 培养其学习兴趣; 对教育培训方而言, 不仅仅为教学设计者提供了能够体现教学过程系统性、完整性的参考和借鉴, 对教育培训所 要达到的教学目标、任务、参训学员学习成效问题也提供了科学指导。 


\section{致谢}

本文为海南省高等学校教育教学改革研究资助项目《海南新型职业农民培养模式研究》 （项目编号：Hnjg2017-50）的阶段性成果之一。

\section{References}

[1] CHEN Xiao-geng, Application of ADDIE Instructional Design Model in Adult Education and Training, Adult Education, No.1, pp. 38-40, 2011.

[2] YANG Xiao-hong,ZHANG Hong-zhuo,and YANG Jing, Establishing Process Model of Teacher Training Based on the ADDIE, Modern Educational Technology,vol.22,pp.16-21, 2012.

[3] WANG Chen-qian, On the Application of Experiential Learning Circle in the Traiing of New Vocational Farmers, Contemporary Continuing Education, vol.33, pp.55-58, 2015. 